\title{
MENINGKATKAN MOTIVASI BELAJAR SISWA DENGAN MENGGUNAKAN MODEL PEMBELAJARAN COMPLETE SENTENCE PADA MATA PELAJARAN BAHASA INDONESIA DI KELAS V SD/MIS MADRISATUL IKBAR TEMBUNG
}

\author{
Nurmayani, Dewi Pratiwi, Sorta Simanjuntak
}

Surel: nur.mayani21@yahoo.co.id

\begin{abstract}
This type of research is Classroom Action Research (CAR), which aims to find out the increase in student motivation in using the complete sentence learning model in Indonesian subjects writing essays in class V SD / MIS Madrisatul Ikbar Tembung. Based on data analysis, that the results of Cycle I Meeting I there were 5 students who were motivated with a percentage of $16.67 \%$ and 25 students were not motivated with a percentage of $83.33 \%$, and at Meeting II there were 7 students who were motivated with a percentage of $23,33 \%$ and 23 students were not motivated with a percentage of $76.67 \%$. In Cycle II Meeting I there were 18 students who were motivated with a percentage of $60 \%$ and 12 students were not motivated with a percentage of 40\%, and at Meeting II there were 29 students who were motivated with a percentage of students $96.67 \%$ and 1 student not motivated by the percentage of students is 3.33\%. Research data from the students' learning motivation questionnaire also increased, namely in the initial condition before the action there was 1 student who experienced high motivation with a percentage of $3.33 \%$ while in the final condition there were 24 students who had high motivation with a percentage of $80 \%$.
\end{abstract}

Keywords : Complete Sentence, motivation to learn, Indonesian Language

\begin{abstract}
ABSTRAK
Jenis penelitian yang digunakan adalah Penelitian Tindakan Kelas (PTK), bertujuan untuk mengetahui peningkatan motivasi belajar siswa dalam penggunaan model pembelajaran complete sentence pada mata pelajaran Bahasa Indonesia materi menulis karangan di kelas V SD/MIS Madrisatul Ikbar Tembung. Berdasarkan analisis data, bahwa hasil pada Siklus I Pertemuan I terdapat 5 orang siswa yang termotivasi dengan persentase $16,67 \%$ dan 25 orang siwa tidak termotivasi dengan persentase $83,33 \%$, dan pada Pertemuan II terdapat 7 orang siswa yang termotivasi dengan persentase $23,33 \%$ dan 23 orang siswa tidak termotivasi dengan persentase $76,67 \%$. Pada Siklus II Pertemuan I terdapat 18 orang siswa yang termotivasi dengan persentase $60 \%$ dan 12 orang siswa tidak termotivasi dengan persentase $40 \%$, dan pada Pertemuan II terdapat 29 orang siswa yang termotivasi dengan persentase siswa 96,67\% dan 1 orang siswa tidak termotivasi dengan persentase siswa 3,33\%. Data penelitian dari angket motivasi belajar siswa juga mengalami peningkatan yaitu pada kondisi awal sebelum tindakan terdapat 1 orang siswa yang mengalami motivasi tinggi dengan persentase $3,33 \%$ sedangkan pada kondisi akhir terdapat 24 orang siswa yang memiliki motivasi tinggi dengan persentase $80 \%$.
\end{abstract}

Kata Kunci : Complete Sentence, Motivasi Belajar, Bahasa Indonesia 



\section{PENDAHULUAN}

Manusia dalam kehidupan sehari-hari tidak akan terlepas dari motivasi. Motivasi itu sangat penting untuk mendorong seseorang tersebut mencapai sesuatu yang dicita-citakan. Peserta didik dikatakan berhasil atau tidaknya tergantung pada motivasi untuk belajar.

Belajar sangat penting bagi kehidupan manusia, manusia selalu senantiasa belajar kapanpun dan dimanapun dia berada guna menambah ilmu pengetahuan. Bukan hanya di lingkungan sekolah, di luar sekolah peserta didik pastinya akan mengalami belajar. Terkadang ada juga peserta didik yang merasa malas untuk belajar, oleh sebab itu guru dituntut memotivasi siswa agar semangat lagi untuk belajar dengan cara memilih model pembelajaran yang efektif dan menyenangkan.

Pembelajaran akan menjadi pembelajaran efektif dan menyenangkan apabila guru mengubah cara mengajar dari model pembelajaran tradisonal menuju pembelajaran inovatif. Dimana caranya melibatkan siswa secara aktif. Pembelajaran tidak lagi berpusat pada guru tetapi pada siswa. Model yang digunakan bukan lagi bersifat menoton melainkan bersifat fleksibel dan dinamis, sehingga dapat menimbulkan kegiatan belajar mengajar menjadi berwarna dan menumbuhkan keberhasilan dalam kegiatan belajar mengajar. Keberhasilan suatu kegiatan belajar mengajar akan sangat mempengaruhi motivasi belajar siswa dalam suatu mata pelajaran terutama mata pelajaran Bahasa Indonesia.

Berdasarkan hasil observasi peneliti terhadap guru kelas $\mathrm{V}$ SD/MIS Madrisatul Ikbar Tembung mengatakan bahwa motivasi belajar siswa masih rendah. Hal tersebut disebabkan karena sebagian besar guru mengajar menggunakan metode ceramah. Dimana cara belajar tersebut bersifat berpusat pada guru.

Bahkan guru menjelaskan materi pada mata pelajaran Bahasa Indonesia sangan menonton sehingga siswa merasa mata pelajaran yang sulit dan membosankan. Sebagai seorang guru harus bisa terampil memilih model pembelajaran yang dapat membuat siswa termotivasi untuk belajar. Dalam kegiatan belajar mengajar guru hanya mengetahui metode ceramah. Akan tetapi dalam hal tersebut, guru kurang terampil memilih model-model pembelajaran yang masa kini. Sehingga guru belum pernah menggunakan model pembelajaran seperti model pembelajaran Complete Sentence.

Oleh sebab itu, cara yang dapat dilakukan guru untuk memotivasi siswa pada mata pelajaran Bahasa Indonesia yaitu dengan menggunakan model pembelajaran complete sentence. Model pembelajaran complete sentence merupakan model pembelajaran yang terdiri dari 3 atau 4 orang secara heterogen, dimana model ini mengarahkan siswa belajar melengkapi paragraf yang belum sempurna dengan menggunakan kunci jawaban yang tersedia. Selain itu 
juga, dengan menggunakan model pembelajaran complete sentence siswa saling membantu bekerja sama dan saling memotivasi dalam melengkapi dan menguasai suatu materi yang disampaikan guru.

\section{METODE PENELITIAN}

Penelitian ini merupakan Penelitian Tindakan Kelas (PTK) yang dikenal dengan nama Classroom Action Reaserch bertujuan untuk mengetahui peningkatan motivasi belajar siswa dalam penggunaan model pembelajaran complete sentence pada mata pelajaran Bahasa Indonesia materi menulis karangan di kelas V SD/MIS Madrisatul Ikbar Tembung. Penelitian ini dilaksanakan selama 2 bulan. Sesuai dengan jenis penelitian ini maka penelitian ini memiliki tahap-thap penelitian yang berupa siklus. Prosedur dalam penelitian menggunakan siklus, tiap siklus dilaksanakan sesuai dengan perubahan yang akan dicapai.

\section{HASIL DAN PEMBAHASAN PENELITIAN}

Pada kondisi awal, hari senin tanggal 29 Juli 2019 angket dibagikan kepada siswa sebelum pembelajaran berlangsung di kelas V-B dengan jumlah siswa 30 siswa terdiri dari 19 siswa perempuan dan 11 siswa lakilaki SD/MIS Madrisatul Ikbar Tembung Tahnu Ajaran 2019/2020. Angket digunakan untuk mengetahui sejauh mana tingkat motivasi belajar siswa sebelum diterapkan model pembelajaran Complete Sentence.
Tabel 1. Persentase Hasil Angket Motivasi Belajar Siswa Kondisi Awal

\begin{tabular}{|c|c|c|c|c|}
\hline NO & $\begin{array}{c}\text { JUMLAH } \\
\text { SISWA }\end{array}$ & $\begin{array}{l}\text { RATA- } \\
\text { RATA }\end{array}$ & KRITERIA & KATEGORI \\
\hline 1 & 1 & $3,33 \%$ & Tinggi & Termotivasi \\
\hline 2 & 9 & $30,00 \%$ & Sedang & $\begin{array}{c}\text { Tidak } \\
\text { Termotivasi }\end{array}$ \\
\hline 3 & 20 & $66,67 \%$ & Rendah & $\begin{array}{c}\text { Tidak } \\
\text { Termotivasi }\end{array}$ \\
\hline Jumlah & 30 Siswa & $100 \%$ & & \\
\hline
\end{tabular}

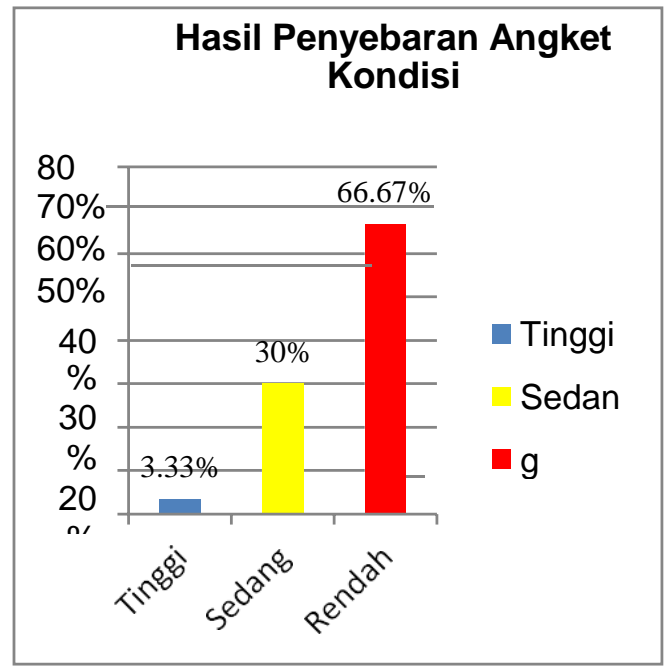

\section{Grafik 1. Penyebaran Angket Motivasi Belajar Siswa Kondisi Awal}

\section{Siklus I}

Masih ada beberapa siswa yang takut untuk mengemukakan pendapatnya serta malu-malu tampil didepan kelas untuk menceritakan hasil kerjanya tentang materi menulis karangan. Pada pertemuan II ketika guru memberikan Lembar Kerja Siswa setiap kelompok lalu siswa setiap kelompok mengerjakan tugas tersebut mulai terlihat aktif meskipun tidak menunjukkan keseluruhan pada siswa. 
Dari data yang doperoleh siswa kelas V-B pada siklus I Pertemuan I dan II dapat disimpulkan masih tergolong rendah. Oleh karena itu, peneliti melanjutkan kegiatan ini agar motivasi belajar siswa dapat mencapai taraf persentase yang diinginkan.

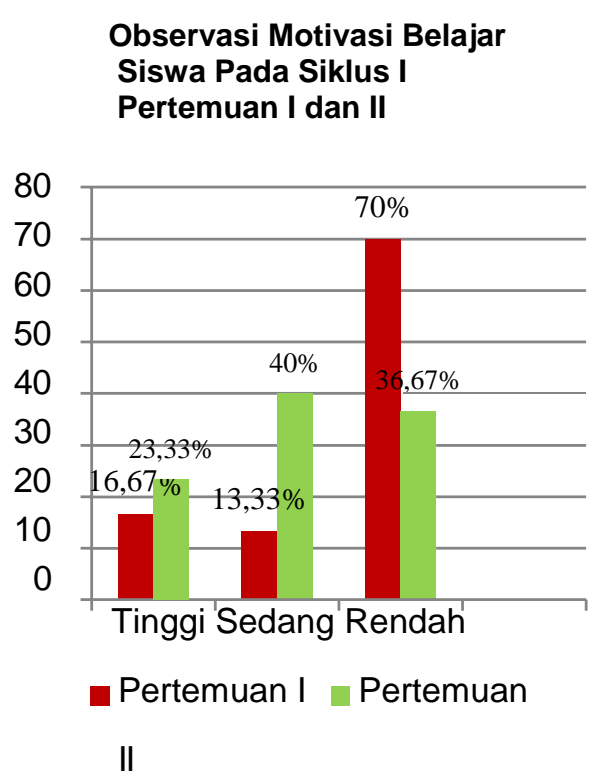

Grafik 2. Observasi Motivasi Belajar Siswa Siklus I Pertemuan I dan II

\section{Siklus II}

Berdasarkan hasil observasi siklus II sebagai berikut : sebagian besar siswa sudah mulai aktif dan termotivasi untuk belajar dan sudah mau mengemukakan pendapatnya serta tidak malu-malu untuk tampil ke depan kelas ketika mempersentasikan hasil diskusinya tentang materi yang sudah dipelajari. Selain itu siswa juga sudah mau mengikuti pembelajaran dengan penuh semangat dan konsentrasi, peneliti telah mampu meningkatkan dan memperbaikki kualitas pelaksanaan pembelajaran. Disini siswa semakin termotovasi untuk bertanya kedapa guru tentang 


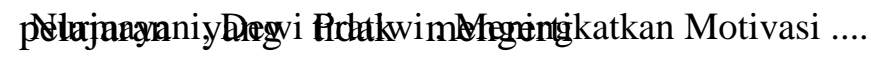

dan menanggapi pertanyaan

teman sekelas dengan percaya

diri. Siswa pun tidak merasa

cepat bosan ketika belajar

Bahasa Indonesia. Kegiatan

kemampuan mengajar guru

sudah ada peningkatan, dimana dalam pengelolaan kelas guru tidak mengalami kesulitan. Pada tahap ini, peneliti merefleksi semua tahapan kegiatan yang dilaksanakan dan disimpulkan bahwa upaya peneliti meningkatkan motivasi belajar siswa telah berhasil.

Setelah selesai pembelajaran, peneliti membagikan angket kondisi akhir kepada siswa.

Tabel 2. Persentase Hasil Angket Motivasi Belajar Siswa Pada Kondisi Akhir

\begin{tabular}{c|c|c|c|c}
\hline No & $\begin{array}{c}\text { Jumlah } \\
\text { Ssiwa }\end{array}$ & $\begin{array}{c}\text { Rata- } \\
\text { rata }\end{array}$ & Kriteria & Kategori \\
\hline 1 & 24 & $80 \%$ & Tinggi & Termotivasi \\
\hline 2 & 6 & $20 \%$ & Sedang & $\begin{array}{c}\text { Tidak } \\
\text { Termotivasi }\end{array}$ \\
\hline Jlh & 30 & $100 \%$ & & \\
\hline
\end{tabular}

Grafik 3. Hasil Penyebaran Angket Motivasi Belajar Siswa Pada Kondisi Akhir

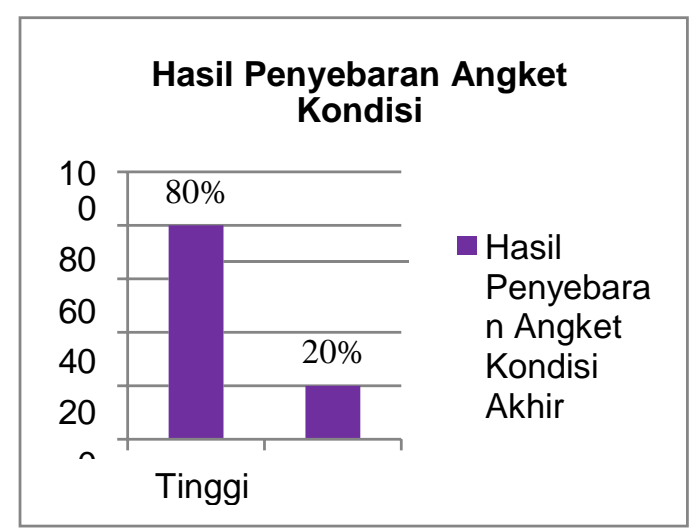


Dari tabel diatas dapat dilihat dengan menggunakan model Complete sentence terjadi peningkatan motivasi belajar siswa yang sangat tinggi.

Berdasarkan hasil penelitian menunjukkan bahwa hasil observasi motivasi belajar siswabahwa hasil pada Siklus I Pertemuan I terdapat 5 orang siswa yang termotivasi dengan persentase $16,67 \%$ dan 25 orang siwa tidak termotivasi dengan persentase $83,33 \%$, dan pada Pertemuan II terdapat 7 orang siswa yang termotivasi dengan persentase $23,33 \%$ dan 23 orang siswa tidak termotivasi dengan persentase $76,67 \%$.

Pada Siklus II Pertemuan I terdapat 18 orang siswa yang termotivasi dengan persentase $60 \%$ dan 12 orang siswa tidak termotivasi dengan persentase $40 \%$, dan pada Pertemuan II terdapat 29 orang siswa yang termotivasi dengan persentase siswa 96,67\% dan 1 orang siswa tidak termotivasi dengan persentase siswa $3,33 \%$

Data penelitian dari angket motivasi belajar siswa juga mengalami peningkatan yaitu pada kondisi awal sebelum tindakan terdapat 1 orang siswa yang mengalami motivasi tinggi dengan persentase $3,33 \%$ sedangkan pada kondisi akhir terdapat 24 orang siswa yang memiliki motivasi tinggi dengan persentase $80 \%$.

\section{SIMPULAN}

Berdasarkan hasil penelitian tindakan kelas yang dilakukan dapat disimpulkan bahwa dengan menggunakan model pembelajaran complete sentence dapat meningkatkan motivasi belajar siswa pada mata pelajaran Bahasa Indonesia materi menulis karangan di kelas $\mathrm{V}$ SD.MIS Madrisatul Ikbar Tembung Tahun Ajaran 2019/2020.

\section{DAFTAR RUJUKAN}

Istarani. 2011. Model Pembelajaran Inovtif. Medan: Media Persada.

Sardiman, A. M. 2011. Interaksi \& Motivasi Belajar Mengajar. Jakarta: Rajawali Pers.

Syamsuarni, dkk. 2014. Pembelajaran Bahasa Indonesia di Kelas Tinggi. Medan: Unimed Press. 